日本臨床外科学会三重県支部抄録

(第 274 回三重外科集談会)

\author{
日 時：平成 22 年 6 月 13 日（日）午後 1 時より \\ 会 場：ホテルグリーンパーク津 $6 \mathrm{~F}$ 伊勢の間
}

1 超高梌にて発症したBochdalek孔へルニアの1例

1. 山田赤十字病院

金芷弘次 ${ }^{1}$ 藤永和寿 $^{1}$ 楠田司 ${ }^{1}$ 宮原成樹 ${ }^{1}$ 高橋幸二 1

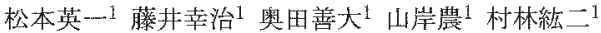

今回われわれは、超高歯にて発症したBochdalek孔へルニア の1例を経験したので報告する。症例は96歳、女性。4 月 程前に左下腹部痛あり近医受診され、左横隔膜へルニアと 診断されている。来院9日前に左上腹部痛委自賞し䁒吐を諗 め、当科入院となった。保存的加療にて症状は軽快した が、胃透視にて胃体部が胸腔内人の脱出しており、食事掑 取不能のため、Bochdalek孔へルニアの診断で第 4 病日に手 術となった。経腹的にアプローチし、Bochdalek孔より胃体 部 - 大網 - 横行〜下行結腸 - 脾臟の脱出老確認した。血流 障害圶認めなかったため、腹腔内一還納し直接綘合閉鎖老 施行した。本症の如く96歳での初発手術症例生稀と考えら れ、若干の文献的考察学加え報告する。

2 ポリソフトを老用いたヘルニア手術の導入

1. 市立四日市病院外科

德永腈策 ${ }^{1}$ 不下敬史 ${ }^{1}$ 蜂須賀丈博 ${ }^{1}$ 柴田雅央1

筒山将之 ${ }^{1}$ 梅田晋 ${ }^{1}$ 鎗田哲惕 $^{1}$ 鹿野敏雄 $^{1}$ 清水大 ${ }^{1}$

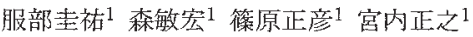

当院では主としてメッシュプラグによる手術毒施行してき た。しかし近年ヘルニアの修復に対して十分な強度を持

ち, 術後疼痛起こしにくいライトウエイトのメッシュ素 材が求められ，前方アプローチで腹膜前修復法に用いるポ リソフトはが発売された。当科で光2009年7月上り使用を開 始した。当科の治療方針は片側のJHS分類 I -3 , II - 3 亿前 カアプローチにてポリソフト孝使用し，ダイレクトクーグ ル法に準じて行っている。また2009年10月からは雨側鼠径 ヘルニアに齐して腹腔鏡下手術を導入し，ポリソフト@をを のま変腔鏡下に挿入するTAPP-Polysoft法を施行してい る，いずれにおいても良好な結果老得ており，その成績之 手技觉㗇告する。
1. 鈴鹿中央病院外科

早崎碧泉 ${ }^{1}$ 出嶂良輔 ${ }^{1}$ 岡本篤之 ${ }^{1}$ 金㫛博司 ${ }^{1}$ 田岡大樹 ${ }^{1}$

【目的】MMGでカテジリー1と判定された乳癌症例の特徽を 明確にする【対象】過去 2 年間に当院で手術施行された乳癌 74 症例の5ち術前診断でMMGカゴリー1と判定された6症例 【与法】1)年粭2) 視螌診3) US4) MMG5) URT6) 手術7)病理結果 の各項目について検討【結果】1)平均年齢53歳2)5例で腫瘤 触知 3$)$ 全例でカテジリー3以上と判定4) 乳腺散在2例, 不均一 高濃度3例 $(50 \%$ ) 5) 5例で悪性在疑わせる所見あり(1例施行

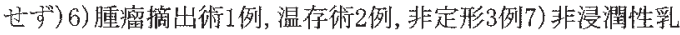
管癌1例, 浸潤性乳管㓡5例【結語】比較的小さく高濃度乳腺 のものがMMGでカテゴリー1と判定される率が高い傾向であ った。これら症例ではMUGのみならず視触診・USの併施が必 須であると思われた。

\section{4 左腎琴部平滑筋肉腫の1例}

1, 県立医療センター外科，2. 目立医療センタ一心臓血管外 科

近藤哲 ${ }^{1}$ 伊藤秀樹 ${ }^{1}$ 今岡裕基 ${ }^{1}$ 志村匡信 $^{1}$ 渡部秀樹 $^{1}$ 横江效1 尾嶋英紀 $^{1}$ 小西尚 ${ }^{1}$ 重盛于香 $^{1}$ 池田哲也 ${ }^{1}$ 登内 - $^{1}$ 近藤智昭 ${ }^{2}$

症例は81歳の女性で、2009年4月下旬、めまいを主訴に当院 循環器科を受診し、高血圧症上診断された。二次性高血庄 症の鑑別のために施行した腹部超音波检査、CTで、左腎門 部に $5 \mathrm{~cm}$ 大の腫瘤を認め、当科入紹介された。3DCTで、腫瘤 に在排された左警動静脈、尿管党認めた。尿細胞診、腫嚓 マーカー（CEA、CA19-9、AFP、可溶性IL-2レセプター）は 陰性だった。6月下旬、後腹膜腫瘤の疑いで、腫瘤摘出術索 施行した。腫瘤は径 $5 \mathrm{~cm}$ の球形で、左腎静脈と強固に癒着 ていた。剥離江困難で、左腎静脈の一部圭合併切除し、人 工血管老用小て血行再貄䘮行った。免疫染色儿上る病理誜 断法平滑筋肉腫で、手術所見などから左腎静脈原発の平滑 筋肉腫と思われた。

5 門脈ガス血症10例の检討

1. 市立四日市病院外科

鹿野敏雄 ${ }^{1}$ 筒山将走 ${ }^{1}$ 梅田晋—1 鉝田哲暢 $^{1}$ 徳永腈策 ${ }^{1}$ 柴田雅央 ${ }^{1}$ 清水大 ${ }^{1}$ 服部圭祐 ${ }^{1}$ 本下敬史 ${ }^{1}$ 蜂須賀丈博 ${ }^{1}$ 森敏宏 ${ }^{1}$ 篠原正䖉 ${ }^{1}$ 宫内正之 ${ }^{1}$

【緒言】門脈分ス血症 (PVG) 㤬腸壊死に伴う予後不艮の兆 候しされてきが、近年、腸壊死を認めないPVG症例も散見さ れる。PVG症例10例老報告し臨床的意義を考察する。【結 果】手術を施行したのは5例、万ち3例が腸壤死で腸切除を 行った。1 例は大腸穿孔で人工肛門造設、1 例泣気腫性襄 胞で試験開腹とした。手術を施行した 5 例中 4 例法軽快退 院となった。手術を施行しなか力た 5 例中 1 例は酎術不 能、翌日に死亡さ机た。他 4 例は腸閉塞加原因で保存的に 軽快した。PVG10例のうちで手術が必要であったのは 5 例、 全例が腹膜刺激症状を呈していた。またPVG症例の救命率は 80\%で女つた。【結語】当院でのPVG症例10例で実際に手術 が必要な症例は $50 \%$ 、高率に救命が可能であった。 
術を施行した一例

上行結腸癌に対し単孔式腹腔鏡下結腸右半切除

1. 三重大学消化管・小坚外科

沖上正人 ${ }^{1}$ 廣純一郎 ${ }^{1}$ 大井正貴 ${ }^{1} 川^{-1}$ 文 $^{1}$ 舆川喜永 $^{1}$

問山裕二 ${ }^{1}$ 井上靖浩 ${ }^{1}$ 三木誓雄 ${ }^{1}$ 楠正人 1

(はじめに) 単孔式腹腔鏡下手術怯、手術難易度は高いもの

の㓣部が小さく整签性にもすぐれ、急速に普及している術 式である。今回、上行結腸癌に対し単孔式腹腔鏡下結腸右 半切除術を施行し良好な経過が得られた一例を経験したの で報告寸る。(症例) 67歳女性。糖尿病、C型肝硬変、肝細胞 癌にて当院にて治療中、FDG-PET CTにて上行結腸に集積を 認めた。精查にて上行結腸癌と診断され治療目的に紹介と なり、単孔式腹腔鏡下結腸右半勿除術(D2) を施行した。手 術時閒は $3: 53$ 。出血量 $14 \mathrm{~g}$ であった。(まとめ) 単孔式腹腔 鏡下大腸切除術の利点を生加大た放には、本術式の特街 十分理解した上で行う必要がありその適応檤重でなけ机 ばならない。

一例

回腸横行結腸側々吻合部に発生した結腸潰煌の

\section{1. 名張市立病院外科}

久保田裕之 ${ }^{1}$ 坪内優宣 ${ }^{1}$ 浦田久志 ${ }^{1}$ 寺邊政宏 ${ }^{1}$

症例は72歳の女性。主訴は右上腹部痛。約50年前に虫垂炎 による沉発性腹膜咨で手術、その後、腸閉塞で手術を受汁 ているが詳細は不明である。ま奇、非代償性肝硬変 (HCV) で 当院内科に通院中であった。一邀間持続する右上腹部痛と 発熱で他院に入院となり、注腸造影上小腸結腸摟学認为、 精查加療目的で転院となった。腹部は平坦軟で臍上部に压 痛を認めた。大腸内視鏡検查で小腸横行結腸短絡側々吻合 と吻合部近傍の結腸に $1 / 4$ 周性の潰瘍病変を2加所認め、㵅 瘍注痛点に一致していた。その他の部位に異常所見は認 めなか力た。病理組織学的に渄特異的な炎症性変化で女 った。以後、絶食輸液管理で経過镜察としていたが敗血症 性ショックと肝不全増悪に上り第18病日死亡した。本例の 潰瘍形成の原因は側々吻合による内容物の衝突と考えられ t。

\section{8} 1. 遠山病院外科

伊藤智恵子 ${ }^{1}$ 重盛恒彦 $^{1}$ 樑谷良 ${ }^{1}$ 毛利智美 ${ }^{1}$ 竹内謙二 ${ }^{1}$ 伊藤佳之 ${ }^{1}$ 加藤俊夫

症例は52歳の男性で、発熱と上腹部痛、腹部膨涧感を訴え 近医索受診し、急性胆囊焱の診断で紹介入院々なった。入 院時、右上腹部に強い㽵痛と腹膜刺激症状があり、

WBC9100/ $\mu$ 1、CRP20. 0mg/d1 と炎症区店高度で、画像診断 上、胆罴は小結石多数上全体に著明な壁肥厚と壁内の裹胞 様変化がみられ胆囊腺筋症が疑われた。保存的治療後、人 院2週目に開腹術を施行した。胆囊任炎症高度で大網に覆わ れ、十二指腸、横行結腸と強く癒着して手拳大の腫瘤椂と なり一部で怔膜下膿㿋を形成していた。胆囊壁を迅速標本 で検索したが悪性像はなく単純胆摘を行った。切除標本肉 眼像加ら黄色肉芽腫性胆囊炎を疑った。病理組織像では胆 囊壁の著明な線維性肥厚、R-Asinus ट全層性の次症細胞浸 潤、泡沫状組織球の集族があり黄色肉芽腫性胆囊炎とされ た。
9 cancer@1例

～僻地医療における局所進行猈癌の位置づけ〜

1 . 紀南病院外科

藤井武宏 ${ }^{1}$ 加藤宏之 ${ }^{1}$ 須崎真 $^{1}$ 野口孝 $^{1}$

はじぬに : borderline resectable pancreatic cancerは專 阴施設に执いてもその手術適応は一定していない。症例： 77歳女性 主訴 : 黄㾝 現病歴 : 黄疸を主訴に受診し、腹 部C下にて膵鈎部に4cm大の腫癌老認めた。膵腫瘍は右半周性 に門脈に隣接して㐨り浸潤が疑示れた。術中所見で注門脈 浸潤部は約 $3 \mathrm{~cm}$ にわたり切除再建を要したが膵頭十二指腸切 除術を施行した。術後病理検查では剥離断圌は陰性でR0手 術が可能であった。結語：borderline resectable pancreatic cancerは予後不良であるが長期予後を得られる 唯一の治潦法は根治術のみであり積極的切除の適応である と考えられた。

10 癌の 1 例

1. 三重大学肝胆膵・移植外科

草深智樹 $^{1}$ 櫻井洋至 ${ }^{1}$ 大拿康生 ${ }^{1}$ 熊本幸司 ${ }^{1}$ 大澤一郎 1 岸和田昌之 ${ }^{1}$ 濱田賢司 ${ }^{1}$ 水野修吾 ${ }^{1}$ 田端正已 ${ }^{1}$ 伊佐地秀司 ${ }^{1}$ 5 年前より、他院にて糖尿病、肝障害でフォロー中、3年前

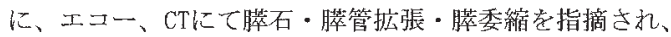
慢性膵炎の診断で経過観察されていた。1年前よりCT, MRIに て膵尾部の腫大を指摘され、増大傾向を認めたため、膵癌

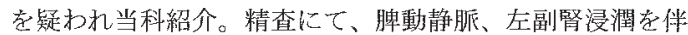
う局所進行膵体部癌T4NOMO Stage IVa (JPS) と診断され、 NCRT索行った後、脾・左副腎合併切除を伴う前方到達法に よる膵体尾部切除術を行った。病理組織の結果では、後腹 膜浸潤や副腎浸潤は指摘されず、脾動静脈への浸潤はな く、最終診断は、UICC T2 No M0 Stag2Bであり、合併 症なく無再発にて経過観察中。

望

1. 三重大学消化管－小児外科，2.三重病院小览外科 井上幹大 ${ }^{1}$ 大井正貴 ${ }^{1}$ 橋本清 ${ }^{1}$ 松下航平 ${ }^{1}$ 小池勇樹 ${ }^{2}$ 大竹耕平 ${ }^{1}$ 廣純一郎 ${ }^{1}$ 内田恵 - - $^{1}$ 三木誓雄 ${ }^{1}$ 楠正人 ${ }^{1}$ 当科では2008年後半より小晿外科領域においても積極的に 内視鏡手術導入L、2008年4例、2009年13例、2010年8例

(4月末現在) と症例は增加傾向にある。この10年間の症 例数注 32 例で、内訳は腹腔鏡下手術では噴門形成術 6 例、 射巣囊腫切除 4 例、Hirschsprung病根治術、脾臟摘出術、

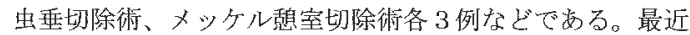
では、メッケル恐室に対する単孔式手術や先天性横隔膜へ ルニア、横隔膜驰緩症に対する胸腔鏡下手術も導入してい る。今回、小児外科領域化特徴的な疾患の手術手技を供覧 するとともに、小坚特有の問題点や今後の展望についても 検討する。 
1.市立四日市病院外科

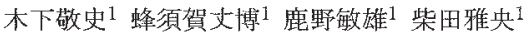

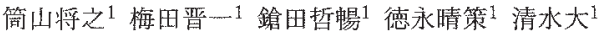

服部圭祐 ${ }^{1}$ 森敏宏 ${ }^{1}$ 篠原正彦 ${ }^{1}$ 宮内正之 ${ }^{1}$

腹腔鏡下胆囊摘出術は標準手術となっている，近年更なる 整容性を求好て，単孔式腹腔鏡下胆囊摘出術が注目を集め ている、しかしデバイスが完全なものでないため，パラレ ル法かクロスハンド法か，真っ直ぐな鉗子を使用するか口 ティキュレーター針子索使用するか，また臍部のポートを どうするか，胆囊底部の挙上どうするかなど定型化には

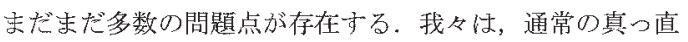
ぐな針子によるパラレル法だけでも鏡視下での鉗子の操作 性夯損なわれず，また整容性においても十分に患者の満足 が得られた脆部の切開創の工夫と方法老考案し，6例に対し て施行したのでその手術手技・成績について報告する.

\section{3 当科に招ける腹腔鏡下虫垂切除術の試み}

1. 三重県立志摩病院外科

飯澤祐介 ${ }^{1}$ 根本明喜 ${ }^{1}$ 山際健太郎 ${ }^{1}$ 勝峰康夫 $^{1}$

近年、デバイスの改良により腹腔鏡手術が盛んに行われる ようになってきた。当院における腹腔鏡下虫垂切除術の試 办について報告卞る。症 1、54歳女性。WBC $10800 / \mu 1$ 、 $\mathrm{CRP} 0.2 \mathrm{mg} / \mathrm{d} 1$ 。CTで腫大した虫垂を認めたが、腹水は諗め なからた。同日、腹腔鏡下虫垂切除術在施行した。虫垂根 部沶Endoloopで処理した。蜂简織炎性虫垂炎であった。症 例2、17歳女性。WBC $16100 / \mu 1 、 \mathrm{CRP} 11.7 \mathrm{mg} / \mathrm{d} 1$ 。Crで膿場 在形成した虫垂索認め、同日、腹腔鏡下虫垂切除術在施行 した。虫垂根部注エンドカッターーで処理し、摘出に㤬回収 用バッグを用いた。壞疽性虫垂炎であった。我々は炎症の 程度の異なる急性虫垂炎に対し腔鏡下虫垂切除術を行以、 良好な結果を得た。今後当症例を積子重视検討老行う。

14 脺腫瘍飞対守る腹腔鏡下膵切除術の適応と成 績 : EUS-FNAによる術前診断の有用性

1 . 三重大学 肝胆膵・移植外科

臼井正信 ${ }^{1}$ 大良康生 ${ }^{1}$ 熊本幸司 ${ }^{1}$ 大澤一郎 1

岸和田昌之 濱田賢司 $^{1}$ 水野修吾 $^{1}$ 櫻井洋至 ${ }^{1}$ 田端正己 ${ }^{1}$ 伊佐地秀司 ${ }^{1}$

【目的】腹腔鏡下睟切除におるけるUUS-FNAの意義について検 討した.【対象と方法】腹望鏡下膵体尾部切除索受けた17例 中, 充害性脺腫䀛で術前EUS-FNA 行った10例老対象. 入院 日数, 膵液瘦, 病理所見および再発について検討。【成績】入 院期閒の中央值は14日で, 膵液瘦はISGPFのgrade Aが3例で 㐫った。病理組織診断は, 内分泌腫瘍3例, SCA 3例, SPA 2例, 自己免疫性膵癌に合併した小膵癌 1 例で, 小膵癌以外確定診 断できていた. 術後視察期間任最長 37 月で, 無再発生存中 である.【結語】腹腔鏡下膵体尾部切除は, EUS-FNAにより良 性・低悪性度の腫煌と判定されたものによい適応と考元ら れた。
15 大腸㩝腹腔鏡下手術における吻合方法の工夫 hemi DST 有いて -

1. 三重県立総合医療センター外科

尾嶋英紀 ${ }^{1}$ 池田哲也 ${ }^{1}$ 志村匡信 $^{1}$ 今岡裕基 $^{1}$ 近藤哲 ${ }^{1}$ 渡部秀樹 ${ }^{1}$ 横江毅 ${ }^{1}$ 伊藤秀樹 ${ }^{1}$ 小西尚 $\mathrm{E}^{1}$ 登内仁 $^{1}$

大腸癌に刘する腹腔鏡下手術は欧米において安全性、根 治性が示されておら、国内でも急速に普及してきている。 当院では2003年に初めて早期大腸癌に対する腹腔鏡下手術 を施行し、2007年からは進行結腸癌や直腸癌に対しても適 応老应大して行っている。その中で、体内吻合の際、当初 はDST (double stapling technique) にて行っていたが、3 例（5.7\%）に縫合不全を認めたため、2009年9月より hemi DSTを施行することとした。以降、現在まで12例で縫合不全 は認わていない。今回、当院における腹腔鏡下大腸癌手術 の現状を、体内吻合時の吻合方法の土夫についてビデオを 供筧し、報告する。

16 遒入 潰崵性大晹炎に対する腹沿鏡下大腸全摘出術の 1. 三重大学医学部消化管 - 小児外科 大北喜基 ${ }^{1}$ 廣純一郎 $^{1}{ }^{\text {荒木俊光 }}{ }^{1}$ 吉山繁幸 $^{1}$ 藤川裕之 $^{1}$ 大井正貴 ${ }^{1}$ 毛利靖彦 $^{1}$ 三未誓雄 ${ }^{1}$ 楠正人 ${ }^{1}$

潰瘍性大腸资 (UC) に対寸る大腸全摘術は，大腸の解剖学的 位置により手術創が大きくなる，腹腔鏡下大腸全摘出術は 腹䏺鏡下大腸手術の中でも手術難易度が高く，ガイドライ ンではHALSが推奖されている。当科で性，小切開下での大 腸全摘術に取り組みHALS と同様の胎下 $7 \mathrm{~cm}$ の皮膚切開による 大腸全摘術を行ってきたが，2009年10月上り巨大中毒結腸 症を認めない全身状態が安定した症例を対像に䎵骨上 $4 \mathrm{~cm} の$ 皮膚切開による腹沿鏡下大腸全摘・J型回晹囊肛門吻合術 導入した. 手術適応や手術時閒短縮などの問題点はあるが 開腹手術と同様の手術が可能で，開腹移行例はなく患者の 満足度も高加た，外科的治療の選抧肢の一つとして腹脉 鏡下大腸全摘出術认有用な術式であると考えられた。

17 結腸切除術

1. 市立伊勢総合病院外科

野田直哉 ${ }^{1}$ 伊藤史人 ${ }^{1}$ 晹淺浩行 ${ }^{1}$ 武内泰司郎 ${ }^{1}$

右側結腸癌に対寸る腹腔鏡補助下結腸切除術において、り ンパ節郭清、血管処理老行う際、後腹膜剥離先行して行 うことが合併損傷回避に有效である。【手術手技】まず頭 低位で回腸末端尾側の後腹膜を切開する。後腹膜下筋膜前 面で上行結腸間膜老頭側们向加て剥離し、十二指腸、膵 起確認し背側一剥離寸る。盲腸、上行結腸背側学十分に剥 離し、十二指腸下行脚右側から横行結腸背側、肝彎曲部ま で剥離しておく。腹側に移り、回結腸動静脈の内側で上行 結晹間膜に切開を加えて後腹膜の剥離層と交通させた後、 リンパ節新清、血管処理を行う。最後に賈高位とし、大網 と肝結腸間膜至切開し後腹膜の剥離層と連続させ、そのま ま上行結腸拉よび旨腸外側を切開し腹腔内操作省終了す る。【まとめ】回腸末端尾側からの後腹膜剥雄は層の把握 が容易で有用である。 
18 術の工夫

1. 三重大学医学部消化管・小見外科

廣純一郎 ${ }^{1}$ 大井正貴 ${ }^{1}$ 川本文 ${ }^{1}$ 沖上正人 ${ }^{1}$ 問山裕二 1 小林美奈子 井上靖浩 $^{1}$ 毛利靖彦 $^{1}$ 三唁雄 ${ }^{1}$ 楠正人 ${ }^{1}$ 直腸癌と胆囊結石に対する腹腔鏡下手術はか゚ート位置が異 な学ため，腹腔鏡下に同時に手術が必要となる場合，下口 カ一数を増やしたり，ポート位置を工夫したりする必要が 㐫り，それぞれの手術を定形化した手技で行うことが難し くなる。当科では，無症侯性胆囊結石と直晹癌在合併した 症例に対して，単孔式腹腔鏡下胆囊摘出術と腹腔鏡下低位 前方切除術在施行し, 単孔式腹腔鏡下胆囊摘出術にて使用 した臍部㓣上り標本在摘出することで良好な経過定経てお り，症例を提示して報告する。胆衰結石を合併した直腸癌 に対しては，単孔式腹腔鏡下手術と腹腔鏡下低位前力切除 術の利点を生かすことで，ポート数や摘出創を増やすこと なく通常のポート位㯰で安全な手術が可能であった。

19 腹壁吊り上げ+胃の創外泮引法による腹腔鏡補 助下幽門側胃切除術

1. 済生会松阪総合病院外科

近藤昭信 ${ }^{1}$ 伊藤貴洋 ${ }^{1}$ 田中攐 ${ }^{1}$ 長沼造史 ${ }^{1}$

当科では腹腔鏡補助下幽門側胃切除 (LADG)において小切開 先先行し、気腹下に胃を創外に搽引しながら鏡視下操作安 行方率引法を行ってきたが、気馥下での問題点を改良し、 腹壁吊り上げの下でも本法が有用であったので報告する。

【方法】1. 上腹部に $5 \mathrm{~cm} の$ 縦切開を加え開腹、創プロテクタ 一老装着、上腹壁の吊り上げを行いながら、5箅所のポート を㧴入。2.創プロテクターを介して肝外側区域をリトラク ターにで頍側に厈排。3.切除胃を創外に牽引し鏡視下にLN 郭清。4. 小開腹創から胃切離と再建。【結果】LADG7例に本 法を施行：全例で気腹への移行なく宗遂。D $1+\beta: 6$ 例、 D1:1例。再建はB-I:5例、Roux-en Y:2例。手術時間 $270 \pm 38$ 分、出血量 : $193 \pm 46 \mathrm{~g}$ は気腹下創外率引法とほぼ同様。

20 腹腔鏡下胃切除術 $(\mathrm{LAG})$ の定型化のための視野 展開之再建法の工夫

1 . 三重大学消化管小昌外科，2. 三重大学先端的外科技鯆開 発学

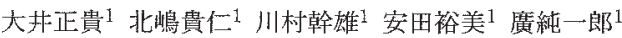

田中光司 ${ }^{1}$ 毛利靖彦 ${ }^{2}$ 三朴瑟雄 ${ }^{1}$ 楠正人 $^{1}$

[はじめに］腹空鏡下敝切除術を定型化するための取り組み を行っている.[対症]2001年より現在すで胃癌に対する腹 腔鏡下胃切除術学 175 症例に施行した。 [方法]術者, 助 手，スコピス下それぞれが場面ごとに決まった形の視野展

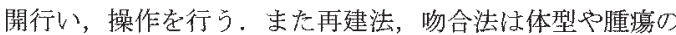
位置，残胃の大きさに関係なく同一の手技で安全に行う。 [結果]平均手術時間 284 分，平均出血量 $104 \mathrm{~g}$ ，術娞平均在 院日数11，4日であった。手術部位感染 (SSI) 発生は9例 (5. 1\%) に謬めた. [考察]腹腔鏡下胃切除術在定型化するに あたっては，術野展開と再建法の土夫が重要と考えられ た。今後さらに症例蓄蓄積し，手技の確立が必要である。
21 経ロアンビルを用いた腹腔鏡下胃全摘術の経験 1. 松阪市民病院外科

下村誠 ${ }^{1}$ 小倉嘉文 ${ }^{1}$ 世古口務 $^{1}$ 谷口健太郎 1 伀藤梨枝 ${ }^{1}$

経ロアンビル (0rVil) を用いたRouY再建定導入し、腹腔鏡 下胃全摘術（以下LATG）を施行したので共覧する。症例は83 歳女性、胃体上部大彎のII c 早期简癌 ( $\mathrm{Tl}$ aNO低分化腺癌) の診断で、D $1+\beta$ リンパ節郭清老伴うLATG在施行した。全 身麻酔下、開脚位にてまず塯直上にカメラポートをおき、 左右 2 力所ずっワーキングポートを执いた。鏡視下にてり

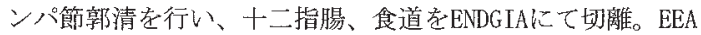
TILT TOP PLUS妾経口的に食道に誘導し、鏡視下に食道断端 から腹腔内に引き抜き、アンビルを食道断端に留置した。 臍直上の創を延長し、小開腹創とし、挙上空腸の断端より circular stapler本体老挿入乙、腹腔内に挿入し、気腹下 に食道空腸吻合を行った。術後経過山良好であった。

22 当科に抒けるLADGの再建〜 CDST法〜

1. 市立四日市病院外科

简山将之 ${ }^{1}$ 木下敬史 ${ }^{1}$ 鹿野敏雄 ${ }^{1}$ 柴田雅央 ${ }^{1}$

徳永 晴策 ${ }^{1}$ 梅田晋 ${ }^{1}$ 鏳田哲暢 ${ }^{1}$ 蜂須賀丈博 ${ }^{1}$ 清水大 ${ }^{1}$

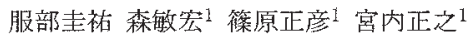

近年，施設によってはLADGは早期胃癌に対する標準手術と なりつつあり，当科でも現在StageIAの胃癌に対しての標準 術式としている。 LADGに扔いてはその再建法がしばしば話 題になっているが我々はBillroth I法再建を行う場合，大 弯の端からサーキュラーステイプラー老挿入する名古屋大 学式のcDST法による再建を行っている。この方法は縫合線 上に吻合するために血流障害の心配が少なく，宗た大弯側 からステイプラーを洀大寸るため残胃への余分な緊張がか からない方法である。2010年5月までに29例に対して施行し たが，現在のところ1例で軽度の吻合部狭窄省経験したのみ で縫合不全は1例も認わていない，ビデオを供覧しその手技 を紹介市る。 